\title{
A new troglobiotic species of Hyalella (Crustacea, Amphipoda, Dogielinotidae) from Southeastern Brazil
}

Giovanna M. Cardoso, Alessandra A. de P. Bueno and Rodrigo L. Ferreira

(GMC, AAPB, RLF) Universidade Federal de Lavras, Departamento de Biologia, Setor de Zoologia, Campus Universitário, CEP: 37200-000, Lavras, Minas Gerais, Brazil. Email: (GMC) jojomonticelli@hotmail.com

\section{Abstract}

The genus Hyalella Smith, 1874 is typical from the continental American waters and show high levels of endemicity. In Brazil, the occurrence of 12 species was reported, of which only Hyalella caeca Pereira 1989 is troglobiotic. A new species was found in a cave, Gruta da Toca, located near Itirapina city, state of São Paulo, Brazil. This species represents the second troglobiotic for the genus in Brazil.

Key words: Diversity, subterranean, groundwater.

\section{Introduction}

Caves present generally a tendency to environmental stability, especially when compared to the surrounding external systems. The cave environment is characterized by the absence of light which prevents photosynthesis. Therefore, the water percolating through the rock and the entry of surface water are important sources of energy for these systems (Bocher et al., 2001; Simon et al. 2003).

Its main forming agent is the water that together with the carbon dioxide becomes acidic and causes the dissolution of minerals as it seeps into the rock. This phenomenon is most common in karst systems, composed primarily of limestone, a more soluble rock (Culver and White, 2005). However, several studies have shown that other types of rock also suffer dissolution processes that are often enhanced by abiotic factors, like temperature (Santos, 2006). Several organisms may use the caves as shelter, but only part of them specializes effectively to underground conditions. These organisms, called troglobiotic, live strictly in caves and are unable to establish viable populations in the external environment (Holsinger and Culver, 1988). There are many morphological differences between the populations of Amphipoda, they generally present some degrees of despigmentation, longer appendages, and compound eyes reduced, and it show distinct degrees in different caves (Culver and Pipan, 2009).

The genus Hyalella Smith, 1874 includes about 52 species, found only in the Americas (Baldinger, 2004). The species of Hyalella live in many freshwater environments, adhered to aquatic vegetation, wetlands or in subterranean environments (Grosso and Peralta, 1999). The first species of the genus occurring in groundwater was Hyalella anophthalma, in Venezuela (Ruffo, 1957). In Brazil, H. caeca is a troglobiotic species found in a cave in the state of São Paulo (Pereira, 1989).

At present, 12 species are known to occur in Brazil: H. gracilicornis (Faxon, 1876); 
H. longistila (Faxon, 1876); H. warmingi Stebbing, 1899; H. meinerti Stebbing, 1899; H. curvispina Shoemaker, 1942; H. brasiliensis Bousfield, 1996; H. caeca Pereira, 1989; H. montenegrinae Bond-Buckup \& Araújo, 1988; H. pseudoazteca González and Watling, 2003; H. dielaii Pereira, 2004; H. pleoacuta González, Bond-Buckup \& Araujo, 2006; $H$. castroi González, Bond-Buckup \& Araujo, 2006 (González et al 2006). For the record, in the state of Sáo Paulo occurs: $H$. caeca; $H$. warmingi epigean species with a cave record, $H$. meinerti and $H$. dielai (González and Watling, 2003; Pereira, 1989; 2004; González et al., 2006). Therefore, the aim of this study was to describe a new troglobiotic species of Hyalella, collected at the Gruta da Toca, Itirapina, state of São Paulo.

\section{Material and Methods}

The specimens were collected in a sandstone cave, Gruta da Toca $\left(22^{\circ} 15^{\prime} 11^{\prime \prime} \mathrm{S}\right.$ $\left.47^{\circ} 49^{\prime} 22^{\prime \prime} \mathrm{W}\right)$, located in the municipality of Itirapina, São Paulo. Only five specimens were found, associated with a sunken tree trunk in a high degree of decomposition, around 100 meters from the cave entrance.

Specimens were dissected and mounted on semipermanent slides. The cephalothorax and total length (from cephalothorax to the distal margin of third urosome) were measured. Morphological characteristics of each appendage were recorded and illustrated with the aim of a camera lucida. The analysis for the description of the species was made based on the paratypes. Type material, holotype and paratypes are deposited in the Museu Nacional do Rio de Janeiro (MNRJ) and Coleção de Invertebrados subterrâneos da Universidade Federal de Lavras (ISLA). The setae terminology follows Zimmer et al. (2009). Descriptions were made according to González and Watling (2003) and González et al. (2006).
Results

Hyalella spelaea sp. nov. Bueno \& Cardoso

(Figs. 1-28)

Types Material: Holotype: male, Brazil, state of Sáo Paulo, Gruta da Toca, Itirapina (2215'11”S 4749'22”W), 22/X/2004, (MNRJ 22586), Ferreira, R. L. col.; Paratype: 2 males (ISLA 1450, ISLA 1451); 1 female (MNRJ 22587), with the same data as the holotype.

Type-locality: Gruta da Toca, Itirapina, SP, Brazil.

Other material examined: Brazil, state of São Paulo: Iporanga: Gruta Tobias de Baixo (MNRJ 7618), Caverna do Diabo (UFLA 032), Caverna Areias II (UFLA 037) and Mirassol: Gruta Mirassol (MNRJ 9539, MNRJ 9540).

Diagnosis: Body surface smooth. Reduced number of ommatidia in the compound eyes. Flagellum of antenna 1 with 9 articles. Flagellum of antenna 2 with 16 articles. Gnathopod 1 carpus slightly longer than propodus, wide posterior lobe with pectinate border and a row of several serrate setae; propodus length twice maximum width (rectangular), hammer-shaped, with combscales near the inner distal margin. Gnathopod 2 carpus wider than long, posterior lobe with pectinate border and several serrate setae; propodus oval, elongated with acute palm, dactylus claw-like, shorter than propodus. Uropod 3 peduncle rectangular with five cuspidate setae with an accessory seta on outer margin; outer ramus with a cuspidate seta and five simple setae. Sternall gills tubular on segments 2 to 6 .

Description of male (Figs. $1-23$ )

Cephalothorax length: $0.52 \mathrm{~mm}$; body length: $4.35 \mathrm{~mm}$ (Fig. 1).

Antenna 1 (Fig. 2) shorter than antenna 2, less than haft of the body lenght. Flagellum with nine articles, aesthetascs occurring distally after article 4.

Antenna 2 (Fig. 3) more than haft of the 
body length, peduncle slender; flagellum with 16 articles.

Basic amphipodan mandible (Serejo, 2004) (Fig. 4) left mandible with incisor toothed, lacinia mobilis with five teeth followed by four papposerrate setae; molar large with one accessory seta.

Upper lip (Fig. 5) margin rounded; distal border covered by short setules on dorsal face. Lower lip (Fig. 6) outer lobes rounded, with setules on dorsal face.

Maxilla 1 (Fig. 7) palp uniarticulate, longer than wide; inner plate slender, shorter than outer plate, with approximately half the length of the outer plate, with two papposerrate setae; outer plate with several serrate setae.

Maxilla 2 (Fig. 8) outer plate larger in length than inner plate, with several simple setae; the inner plate with two papposerrate setae, several simple and serrate setae.

Maxilliped (Fig. 9) inner plate with three cuspidate setae apically, serrate setae and several pappose setae in the border; outer plate apically truncated; palp with four articles, with simple setae; dactylus unguiform, shorter than third article, distal nail present.

Gnathopod 1 (Fig. 10) subchelate; carpus slightly longer than propodus, wide posterior lobe with pectinate border and a row of several serrate setae; propodus length twice maximum width (rectangular), hammershaped, with comb-scales near the inner distal margin, ventral face with serrate setae, simple setae on the inner margin, palm transverse with several simple setae and cuspidate setae with an accessory seta; dactylus claw-like, with one plumose seta (Fig. 11).

Gnathopod 2 (Fig. 12) subchelate; carpus wider than long, posterior lobe with pectinate border and several serrate setae; propodus oval, elongated with acute palm, several simple setae and cuspidate setae with an accessory seta, several long simple setae on distal margin; dactylus claw-like, shorter than propodus, with one plumose seta dorsally (Fig. 13).

Pereiopods 3 to 7 (Figs.14-18) simple, gradually increasing in length, coxae with several simple setae on the border; ischium, merus and carpus with simple setae and cuspidate with an accessory seta at distal margin; dactylus less than half of propodus's length, unguiform.

Pleopods (Fig. 19) not modified; peduncle slender with two coupling spines; rami nearly two times larger than peduncle with plumose setae.

Uropod 1 (Fig. 20) longer than uropod 2; peduncle longer than rami, with cuspidate setae with an accessory seta on the inner margin; rami subequal; outer ramus with four cuspidate setae on the inner margin (three of them with an accessory seta), apex with four cuspidate setae, one of them with an accessory seta; inner ramus with two cuspidate setae with an accessory seta on inner margin, three cuspidate setae and five cuspidate setae with an accessory seta apically.

Uropod 2 (Fig. 21) peduncle rectangular with similar size rami; inner margin with simple setae and a cuspidate seta with an accessory seta; outer ramus slightly, smaller than inner ramus, with cuspidate setae with an accessory seta on the inner margin, apex with four cuspidate setae (one with an accessory seta); inner ramus with two cuspidate setae with an accessory seta on the inner margin, apex with eight cuspidate setae (five of them with an accessory seta).

Uropod 3 (Fig. 22) similar in length to uropod 2 peduncle; peduncle rectangular with five cuspidate setae with an accessory seta on outer margin; outer ramus with a cuspidate seta and five simple setae, ramus basis 3.5 times larger than apex.

Telson (Fig. 23) slightly wider than long with two simple setae apically.

Coxal gills sac-like on segments 2 to 7 .

Sternall gills tubular on segments 2 to 6 .

Female (Figs. 24-28)

Cephalothorax length: $0.35 \mathrm{~mm}$.

Antenna 1 flagellum with seven articles, asthetascos occurring distally after article three. Gnathopod 1 (Fig. 24 and 25) similar to male gnathopod, except for four dorsal setae on dorsal face of palm; hammer-shaped; carpus slightly longer than propodus, wide posterior 


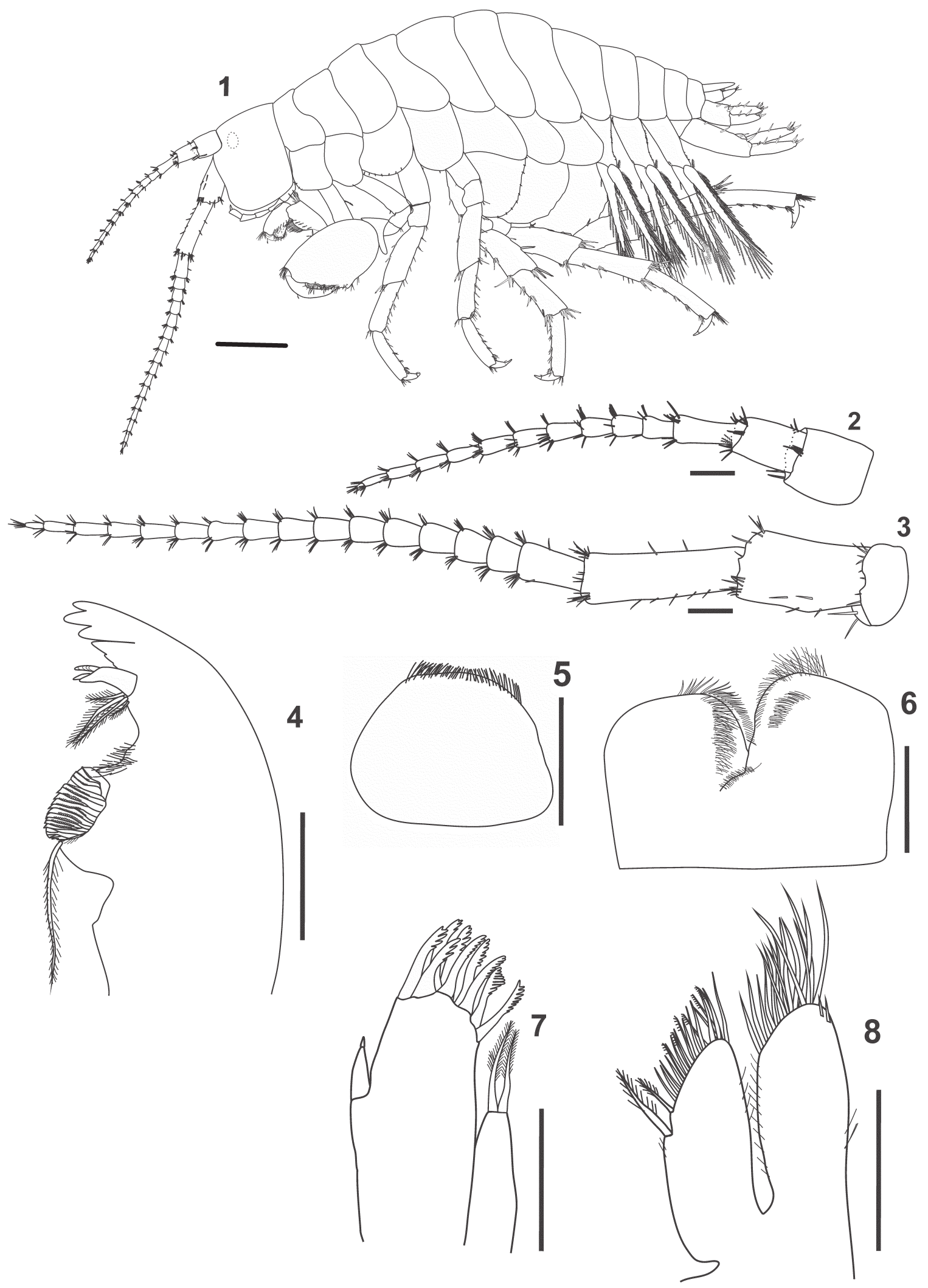

Figures 1 to 8. Hyalella spelaea n. sp. Male. 1 lateral view; 2 antenna 1; 3 antenna 2; 4 left mandible; 5 upper lip; 6 lower lip; 7 maxilla 1; 8 maxilla 1. Scales: (1): $1 \mathrm{~mm},(2,4-8): 0.1 \mathrm{~mm}(3): 0.2 \mathrm{~mm}$. 

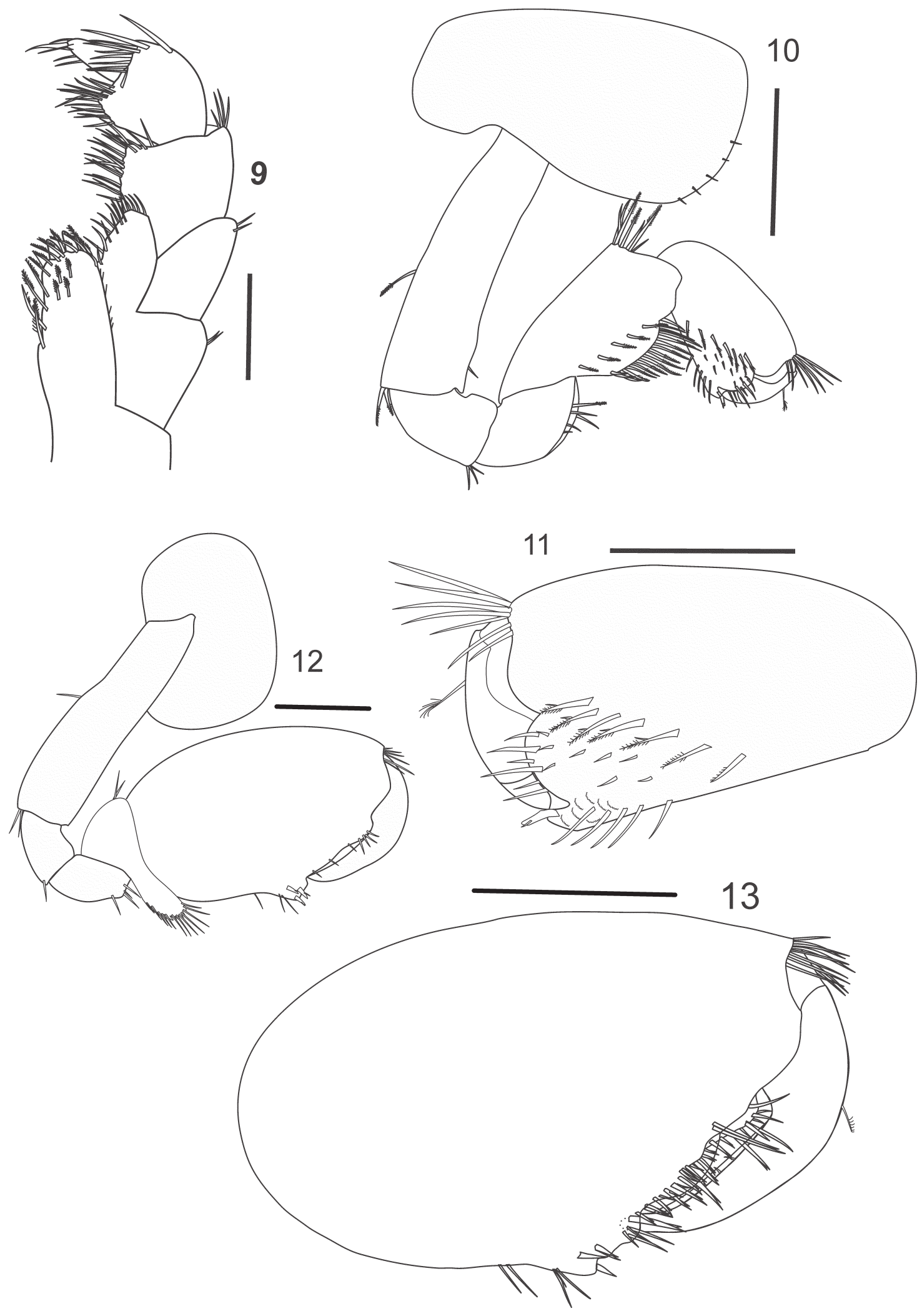

Figures 9 to 13. Hyalella spelaea n. sp. Male. 9 maxilliped; 10 gnathopod 1;11 detail of dactylus and propodus of gnathopod 1 dorsal view; 12 gnathopod 2; 13 detail dactylus and propodus of gnathopod 2 ventral view. Scales: (9-13): $0.1 \mathrm{~mm}$. 


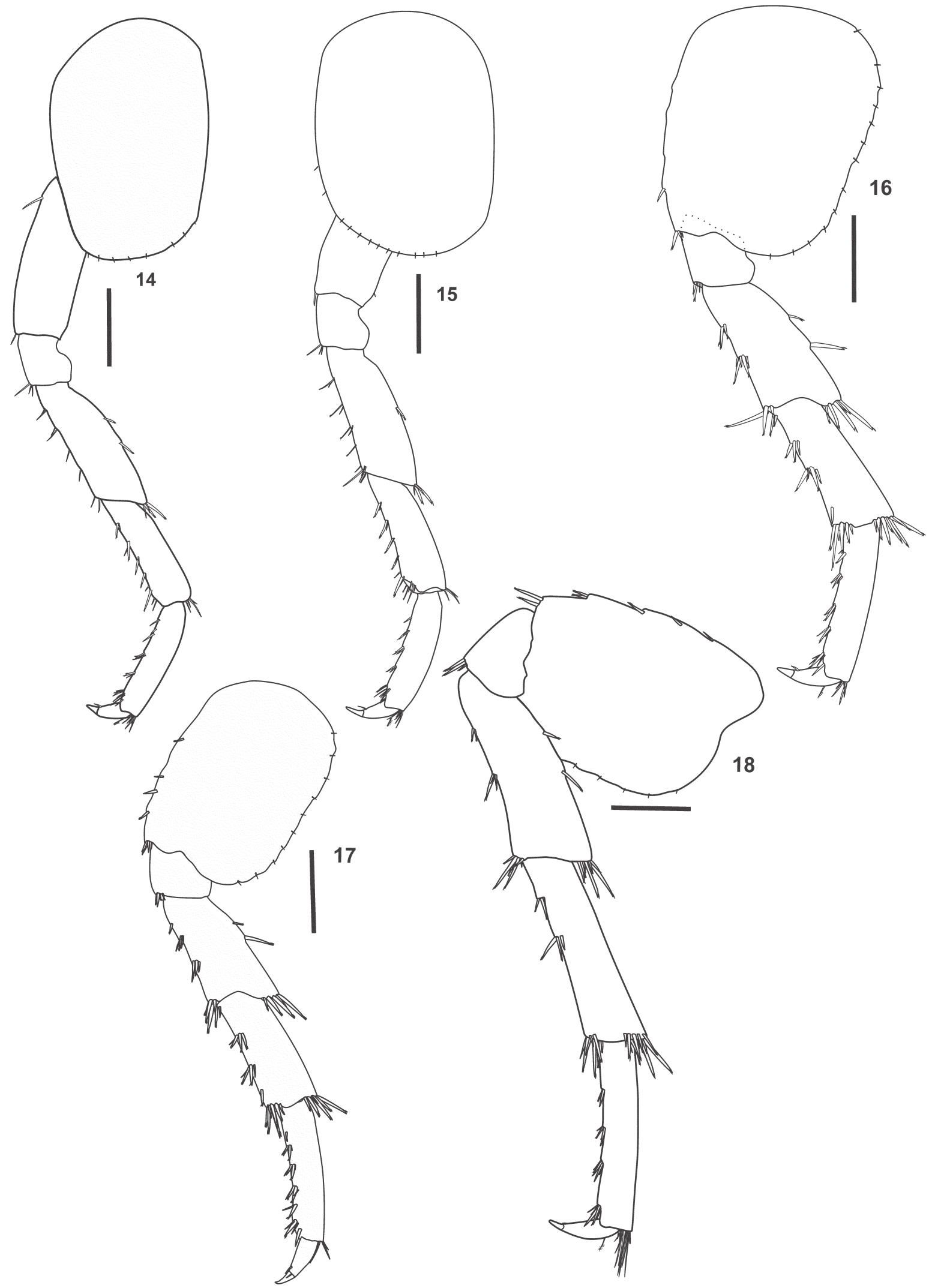

Figures 14 to 18. Hyalella spelaea n. sp. Male. 14 pereiopod 3; 15 pereiopod 4; 16 pereiopod 5; 17 pereiopod 6; 18 pereiopod 7. Scales: (14-18): $0.2 \mathrm{~mm}$. 

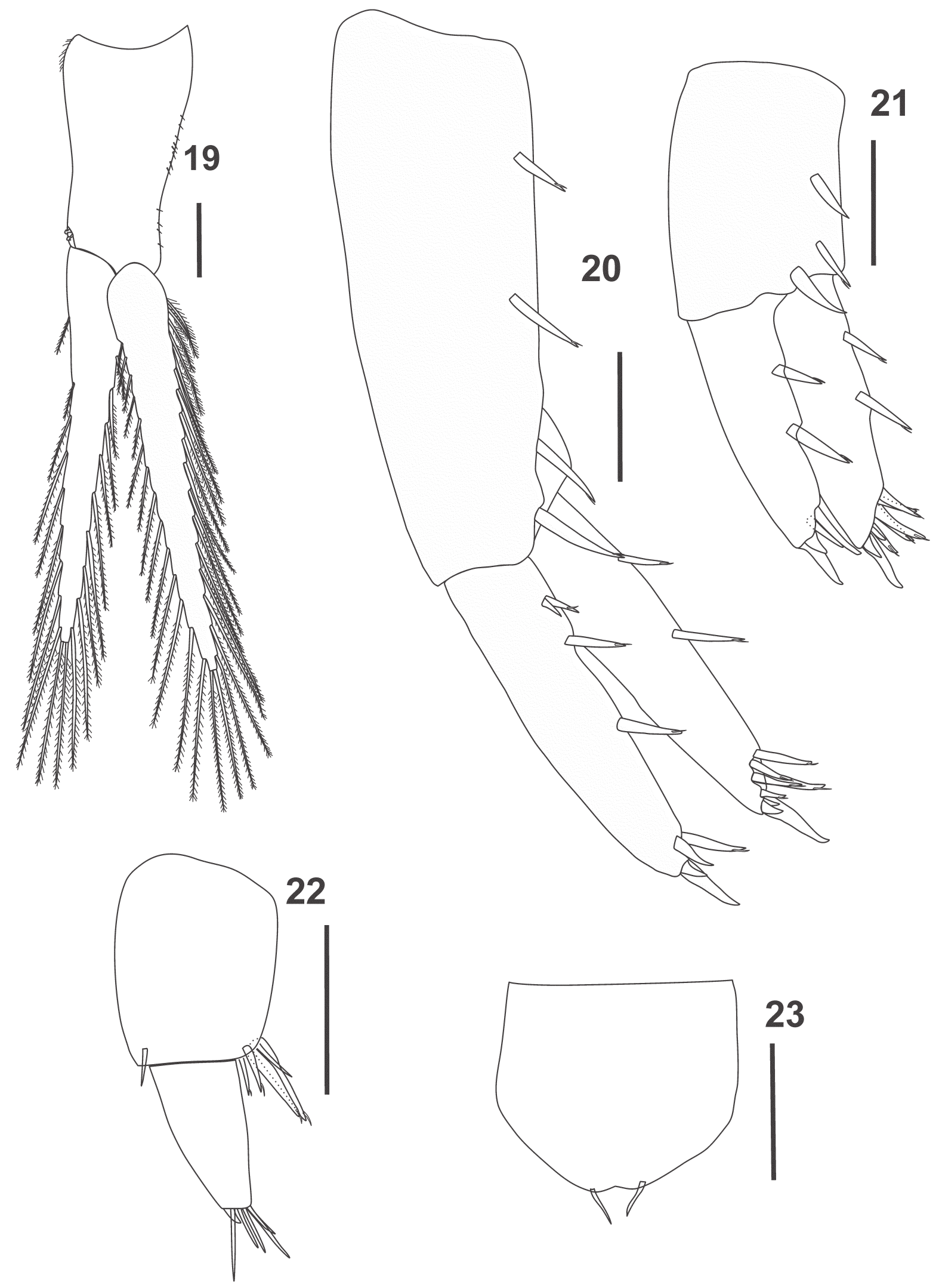

Figures 19 to 23. Hyalella spelaea n. sp. Male. 19 pleopod 1; 20 uropod 1; 21 uropod 2; 23 uropod 3; 24 telson. Scales: (19 to 24): $0.1 \mathrm{~mm}$ 




Figures 24 to 28. Hyalella spelaea n. sp. Female. 24 gnathopod 1 ventral view; 25 detail of dactylus and propodus of gnathopod 1 dorsal view; 26 gnathopod 2 ventral view; 27 detail dactylus and propodus of gnathopod 2 dorsal view; 28 telson. Scales: (24-28): $0.2 \mathrm{~mm}$. 
Table 1. Male morphological characters of troglobiotic species of Hyalella. (G1: gnathopod 1, G2: gnathopod 2).

\begin{tabular}{lccc}
\hline Characters & $\begin{array}{c}\text { H. anophthalma } \\
\text { Ruffo, 1957 }\end{array}$ & $\begin{array}{c}\text { H. caeca } \\
\text { Pereira, 1989 }\end{array}$ & $\begin{array}{c}\text { H. spelaea } \\
\text { sp.n. }\end{array}$ \\
\hline $\begin{array}{l}\text { Antenna 1 - Number of } \\
\text { articles of flagellum }\end{array}$ & 6 & 10 & 9 \\
$\begin{array}{l}\text { Antenna 2- Number of } \\
\text { articles of flagellum }\end{array}$ & 9 & 14 & 16 \\
$\begin{array}{l}\text { Maximum Total length } \\
\text { Maxilla 1 - outer plate }\end{array}$ & $3.2 \mathrm{~mm}$ & $6.0 \mathrm{~mm}$ & $4.35 \mathrm{~mm}$ \\
$\begin{array}{l}\text { G1- comb scales propodus } \\
\begin{array}{l}\text { G2- lobiform process of } \\
\text { propodus }\end{array}\end{array}$ & Present & 9 serrate setae & 9 serrate setae \\
$\begin{array}{l}\text { G2- propodus } \\
\begin{array}{l}\text { Uropod 1/ Uropod 3 } \\
\text { ratio }\end{array}\end{array}$ & $\begin{array}{c}\text { Length 1.5 times } \\
\text { larger than width }\end{array}$ & $\begin{array}{c}\text { Length 1.46 times larger } \\
\text { than width }\end{array}$ & $\begin{array}{c}\text { Length } 1.53 \text { times } \\
\text { larger than width }\end{array}$ \\
\hline
\end{tabular}

lobe with pectinate border and a row of several serrate setae.

Gnathopod 2 (Fig. 26 and 27) subchelate, propodus subrectangular, longer than wide, with a row of three serrate setae on ventral face, palm transverse.

Telson (Fig. 28) with two simple setae apically and two groups of three submarginal setae with plumose setae, at each side of the telson. Others characters similar to the male.

Habitat: hipogean; Gruta da Toca, Itirapina, São Paulo, Brazil.

Etymology: the species name, spelaea, refers to the habitat where the species was found.

Remarks: The new specie present different characteristic such as: reduction in number of ommatideas, gnathopod 1 rectangular shape with comb-scales; palm of gnathopod 2 has the same size and dactylus shorter than the palm; reduction in the number of setae in appendices. Analyzing the paratypes of Hyalella caeca found the following differences with the new species the gnathopod 1 of H.caeca has a quadrangular propodus and does not present comb scales, while $H$. spelaea has a rectangular propodus on gnathopod 1 and presents comb-scales; the second gnathopod of
$H$. caeca shows the propodus palm longer than posterior margin and a long dactylus (as long as propodus palm), while $H$. spelaea shows the propodus palm as long as posterior margin and dactylus shorter than propodus palm. Uropod 1 and 3 of H.caeca is more setose than $H$. spelaea; uropod 3 peduncle of H.caeca is longer than ramus, what cannot be observed on H.spelaea (in which U3 peduncle is as long as ramus). Moreover, differences can be noted when compared to $H$. warmingi, a species that don't have troglomorphic traits despite of having already been collected in a cave. These are: the absence of comb-scales in gnathopod 1 , dactylus of gnathopod 2 congruent with the palm and well developed eyes.

The new species is restricted to the environment where it was found, raising the caves' relevance status. Thus, future knowledge of biodiversity can be used underground for the conservation, management and monitoring of wildlife in natural areas (Ferreira, 2005).

\section{Acknowledgments}

We thank Marconi Souza Silva for his assistance in the field work, Critical Ecosystem Partnership Fund (CEPF), Conservação 
Internacional (CI), ICMBIO - CECAV and Fundação S.O.S Mata Atlântica; and to Rafaela Bastos Pereira for her assistance in the laboratory. We'd also like to thank the entire staff of the Laboratory of Underground Ecology of the Section of Zoology of the Federal University of Lavras (UFLA) for their efforts in the collection.

\section{References}

Baldinger, A.J. 2004. A new species of Hyalella (Crustacea: Amphipoda: Hyalellidae) from Ash Springs, Lincoln County, USA, with a key to the species of the genus in North America and the Caribbean region. Journal of Natural History 38: 1087-1096.

Bocher, P.; Cherel, Y.; Labat, J.F.; Mayzaud, P.; Razouls, S. and Jouventin, P. 2001. Amphipod-based food web: Themisto gaudichaudii caught in netsand seabirds in Kerguelen waters, southern Indian Ocean. Marine Ecology Progress Series, 223: 261276.

Culver, D.C. and White, W.B. 2005. Encyclopedia of Cave. San Diego, California: Elsevier. 654p.

Culver, D.C. and Pipan, T. 2009. The Biology of Caves and Other Subterranean Habitats. Oxford University Press Inc., New York. 273p.

Ferreira, R.L. 2005. A vida subterrânea nos campos ferruginosos. $O$ Carste, Belo Horizonte, 17(3): 106-115.

González, E.R. and Watling, L. 2003. A new species of Hyalella from Brasil (Crustacea: Amphipoda: Hyalellidae), with redescriptions of three other species in the genus. Journal of Natural History, 37(17): 2045-2076.

González, E.R; Bond-Buckup, G. and Araujo, P.B. 2006. Two new species of Hyalella from Southern Brazil (Amphipoda: Hyalellidae) with a taxonomic key. Jounal of Crustacean Biology, 26(3): 355-365.
Grosso, L. and Peralta, M. 1999. Anfípodos de agua dulce sudamericanos. Revisión del género Hyalella Smith. I. Acta Zoologica Lilloana, 45(1): 79-98.

Holsinger, R. and Culver, D.C. 1988. The Invertebrate Cave Fauna of Virginia and a Part of Eastern Tennessee: Zoogeography and Ecology. Brimleyana, 14: 1-162.

Pereira, V.F.G. 1989. Uma nova espécie de anfípode cavernícola do Brasil - Hyalella caeca sp. n. (Amphipoda, Hyalellidae). Revista Brasileira de Zoologia, 6(1): 49-55.

Pereira, V.F.G. 2004. Hyalella dielaii sp. nov. from São Paulo, Brazil (Amphipoda, Hyalellidae). Revista Brasileira de Zoologia, 21(2):179-184.

Ruffo, S. 1957. Una nuova specie troglobia di Hyalella del Venezuela. Estrato Dauli Annali del Museo Civico Di Storia Naturale Di Genova, 69: 363-369.

Santos, S.R.F. 2006. Espeleogênese dos abrigos areníticos com registros arqueológicos no Centro-Norte Catarinense. Master Dissertation, Universidade Federal de Santa Catarina. Florianópolis/SC.

Serejo, C.S. 2004. Cladistic revison of talitroidean amphipods (Crustaces, Gammaridean), with a proposal of a new classification, The Norwegian Academy of Science and Letters. Zoologica Scripta, 33(6): 551-586.

Simon, K.S.; Benfield E.F. and Macko, S.A. 2003. Food web structure and the role of epilithic films in cave streams. Ecology, 84: 2395-2406.

Zimmer, A.; Araujo, P.B. and Bond-Buckup, G. 2009. Diversity and arrangement of the cuticular structures of Hyalella (Crustacea: Amphipoda: Dogielinotidae) and their use in taxonomy. Zoologia, 26(1):127-142. 